\title{
Short Communication: Duration and volume of crowing of Pelung chickens of West Java, Indonesia
}

\author{
INDRAWATI Y. ASMARA ${ }^{\mathbf{1}}$, DANI GARNIDA ${ }^{\mathbf{1}}$, RUHYAT PARTASASMITA ${ }^{2, \bullet}$ \\ ${ }^{1}$ Faculty of Animal Husbandry, Universitas Padjadjaran. Jl. Raya Bandung-Sumedang Km 21, Jatinangor, Sumedang 45363, West Java, Indonesia \\ ${ }^{2}$ Department of Biology, Faculty of Mathematics and Natural Sciences, Universitas Padjadjaran. Jl. Raya Bandung-Sumedang Km 21, Jatinangor, \\ Sumedang 45363, West Java, Indonesia. Tel.: +62-22-7796412 line. 104, Fax.: +62-22-7794545, •email: ruhyat.partasasmita@unpad.ac.id; \\ rp2010rikkyo@gmail.com
}

Manuscript received: 24 December 2019. Revision accepted: 24 January 2020

\begin{abstract}
Asmara IY, Garnida D, Partasasmita R. 2020. Short Communication: Duration and volume of crowing of Pelung chickens of West Java, Indonesia. Biodiversitas 21: 748-752. Pelung are long crowing chickens originally from West Java Province, Indonesia. The chickens are raised as singing birds due to their beautiful crowing capability. Nowadays, the chickens are distributed not only in West Java, Indonesia but also in other provinces in Indonesia because of the existence of Pelung contests. The contests evaluate singing ability of Pelung chickens and are important promotion media for the birds. In contests, crowing characteristics such as duration and intensity are important factors to determine the quality of chickens. Some factors such as age, body weight, and body morphometrics are assumed to influence crowing characteristics. The study was aimed to determine crowing duration and volume in Pelung roosters, as well as correlations of age, body weight and body morphometrics with crowing characteristics. A survey was performed to collect data involving 73 birds in two areas in West Java Province. The research locations are Cianjur and Sukabumi Districts. The results showed that roosters in all areas have similar crowing durations, while their crowing intensities are varied. The study also found that age and body weight, as well as some body-morphometries, have strong correlations with crowing characteristics. The research provides empirical evidence of factors determining vocal performance of Pelung chickens. However, more samples from different areas are required to support these findings. In addition, research on management systems, health status and participation of chickens in rehearsal is needed in the future.
\end{abstract}

Keywords: Crowing, duration, Pelung, volume

\section{INTRODUCTION}

Chickens are the most abundant domesticated species in the world besides cattle, sheep, goats, and pigs. Half of the chicken population is found in Asia (FAO 2007) and it was reported that chickens were firstly domesticated in this continent. Together with China and India, Indonesia is considered to be one of th world's centers of chicken domestication (Sulandari et al. 2008). More than 30 different groups of chickens inhabit the Indonesian archipelago (Nataamijaya 2000), which can be divided into two categories; descript and nondescript chickens (Directorate General of Livestock Services 2003). Descript chickens can be identified by their plumage and commonly found in specific areas, while non-descript chickens do not have unique plumage and distribute widely across islands of Indonesia (Diwyanto and Iskandar 1999).

In general, chicken diversity is a result of demographic migration (Sartika et al. 2004) and farmer preferences (Komiyama et al. 2016; Bortoluzzi et al. 2018). Farmer preferences contribute significantly in developing chickens for specific uses such as for entertainment purposes (Komiyama et al. 2016; Bortoluzzi et al. 2018). Some chickens in Indonesia have been maintained by farmers because of their unique sounds, for example, kokok balenggek chickens from West Sumatera Province, gaga or ketawa chickens from South Sulawesi Province, and Pelung chickens from West Java Province (Sulandari et al. 2007).

In Java Island, Pelung chickens are indigenous and are probably the most well-known chickens due to their capability of crowing (Nataamijaya 2000; Partasasmita et al. 2016, 2018; Asmara et al. 2018). They were first developed by people in Cianjur District, West Java Province, and have become iconic for this area. Pelung has the capacity to crow long and rhythmically for 11 (Nataamijaya 2005) and even up to 15 seconds (Hippapi Kabupaten Cianjur 2005). Besides its unique crowing, Pelung can be recognized by its distinct body conformation. The bodyweight of Adult male Pelung chickens is about $5,400 \mathrm{~g}$, while female adult is about $4,500 \mathrm{~g}$. The hens yield $39-68$ eggs annually. The plumage color of Pelung chickens is commonly dominated by red, black and green for male chickens, and black for females (Sulandari et al. 2007).

Pelung chicken has been officially declared as an indigenous chicken breed and part of Animal Genetic Resources (AnGRs) in Indonesia, through Decree No. 2918/2011 issued by the Ministry of Agriculture. The decree stated that Pelung chickens require protection and 
conservation. However, Asmara (2014) reported that Pelungs are endangered due to their decreased population sizes. Fortunately, among other local chickens such as Sentul and Kedu chickens, Pelung chickens are less likely to go extinct due to its socio-economic value. The socioeconomic value of Pelung chickens is supported by Pelung contests, which are conducted regularly.

The existence of Pelung contests plays an important role in population distribution of the chickens; thus it would increase Pelung population. Because of the contests, Pelung chicken has spread across West Java and other provinces in Indonesia (Asmara 2014). Chicken contests are perceived by farmers as markets to find good breeds, and to broaden their knowledge about Pelung management system as well as a market place (Asmara et al. 2018). The price of winning roosters increases as they win contests. As a consequence, their fertile eggs and/or offspring would also be valued more highly (Asmara 2014). There are two categories in Pelung contests; singing and performance categories. Chickens with longer crowing duration and more distinct sound characteristics typically win contests. To excel in the performance category, chickens should have minimum body weights of $5,000 \mathrm{~g}$, with color uniformity of their plumage, beak, and shank.

Crowing duration, intensity, and rhythm may indicate the quality of a good Pelung rooster (HIPPAPI 2012). It is believed by Pelung keepers that crowing ability of Pelung chickens is inherited from their parents (HIPPAPI 2012), mainly from the dams (Muladno 2008). In particular, the keepers believe that duration and intensity (volume) of crowing is influenced by age, body weight and health status (HIPPAPI 2012). A rooster aged less than 12 months usually has shorter crowing duration than that of older age. Similarly, unhealthy roosters tend to have shorter crowing duration. In terms of crowing intensity, a heavier rooster is thought to have lower intensity. The objective of study was to determine duration and volume of crowing of Pelung chickens. Correlations between intensity and duration with age, body weight and morphometric of Pelung chickens were also determined. The study was conducted to provide empirical evidence of farmer knowledge about crowing characteristics; thus the findings would be helpful for Pelung chickens' management system.

\section{MATERIALS AND METHODS}

\section{Description of research area}

The study was conducted in Cianjur and Sukabumi Districts, West Java Province, Indonesia (Figure 1). The two districts are adjacent to each other in southwestern Java Island. Situated at an altitude of 7-2,962 m, Cianjur District has rainfall of 2,610 mm with temperature of 24.4 ${ }^{\circ} \mathrm{C}$ annually (Cianjur District Office of Information Communication and Statistics 2017). The altitude of Sukabumi District is $0-2,960 \mathrm{~m}$. The district has rainfall of $2,000-4,000 \mathrm{~mm}$ and temperature $18-30^{\circ} \mathrm{C}$ annually (Sukabumi District Government 2016).

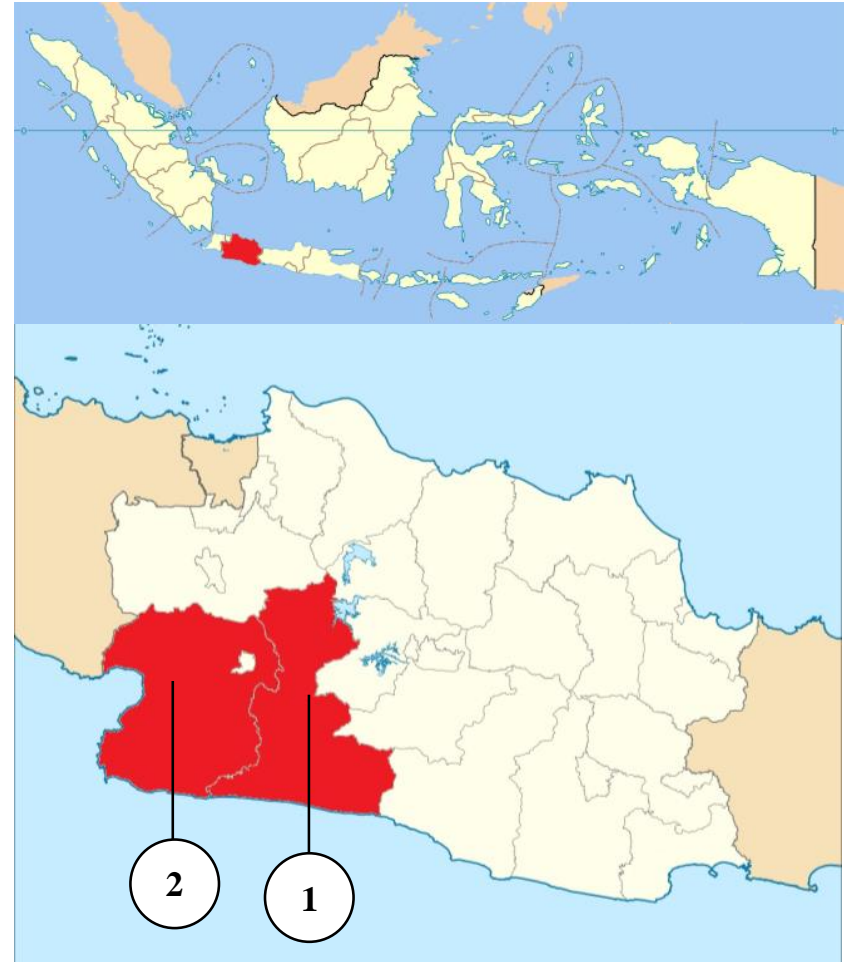

Figure 1. Research areas in Cianjur (1) and Sukabumi (2) Districts, West Java Province, Indonesia

\section{Research methodology}

The study used survey method involving 73 chickens in two study areas. The collecting data applied purposive sampling method since no precise information was available regarding the number of Pelung chickens in the research locations. The samples were male Pelung with minimum ages of 6 months old, and consisted of 33 birds from Cianjur and 40 birds from Sukabumi district. The roosters were placed in bamboo cages called 'ajeng' to record the crowing sound. The dimension of cage is $80 \mathrm{~cm}$ (length), $80 \mathrm{~cm}$ (width) and $100 \mathrm{~cm}$ (height) and each cage is placed above the ground with height of $80 \mathrm{~cm}$. The crowing sound was recorded in $\mathrm{mp} 3$ format using digital voice recorder which was positioned at one side of cage near roosters' head. The sound was recorded three times for each sample. Then, recorded sound was analyzed with Audacity 2.3 to determine duration and intensity of crowing. Weights of chickens were measured by a digital scale. The morphometric measures including length and circumference of neck; length, width, and circumference of chest; and width of pubic bone. All were measured using tape measures or calipers. Data were analyzed using descriptive analysis and correlation analysis. The correlation coefficient (a value between-1 and +1 ) determines the relationship strength between two variables. A correlation coefficient of +1 shows a perfect positive correlation, while a correlation coefficient of -1 indicates a perfect negative correlation. The correlation analysis applied non-parametric rank spearman analysis. Microsoft excel 2016 was used for data analysis. 


\section{RESULTS AND DISCUSSION}

\section{Results}

Table 1 shows descriptive analysis of age, body weight and crowing characteristics (duration and intensity) of Pelung roosters in research area. The average of chicken age is 9.23 months; body weight is $3.94 \mathrm{~kg}$, crowing duration is 8.56 seconds, and intensity is 50.11 decibel. The data of age, body weight and crowing duration of sample tend to be uniform except for crowing intensity. The coefficient of variation for intensity is very high $(67.25 \%)$ indicated less uniformity of data.

In terms of body morphometrics, the average of length and circumference of neck are $22.08 \mathrm{~cm}$ and $12.65 \mathrm{~cm}$ respectively. The mean of length, width, and circumference of chest are $14.82 \mathrm{~cm}, 8.81 \mathrm{~cm}$, and $38.82 \mathrm{~cm}$ respectively. The average length of pubic bone is $2.62 \mathrm{~cm}$. The coefficient of variation body morphometric is low indicated uniformity of data (Table 2).

Table 1. Age, body weight and crowing characteristics of male Pelung chickens

\begin{tabular}{|c|c|c|c|c|}
\hline \multirow[b]{2}{*}{$\begin{array}{l}\text { Descriptive } \\
\text { parameter }\end{array}$} & \multirow[b]{2}{*}{$\begin{array}{c}\text { Age } \\
\text { (month) }\end{array}$} & \multirow{2}{*}{$\begin{array}{c}\text { Bodyweight } \\
\text { (kg) }\end{array}$} & \multicolumn{2}{|c|}{ Crowing characteristics } \\
\hline & & & $\begin{array}{c}\text { Duration } \\
\text { (second) }\end{array}$ & $\begin{array}{l}\text { Intensity } \\
\text { (decibel) }\end{array}$ \\
\hline Mean & $9.23 \pm 2.22$ & $3.94 \pm 0.49$ & $8.56 \pm 1.53$ & $50.11 \pm 8.20$ \\
\hline Minimum & 7.00 & 3.01 & 5.17 & 25.96 \\
\hline Maximum & 18.00 & 4.90 & 12.33 & 62.48 \\
\hline $\begin{array}{l}\text { Coefficient of } \\
\text { variation }(\%)\end{array}$ & 4.93 & 0.24 & 2.35 & 67.25 \\
\hline
\end{tabular}

Table 2. Body morphometric of male Pelung chickens

\begin{tabular}{lcccccc}
\hline \multirow{2}{*}{$\begin{array}{l}\text { Descriptive } \\
\text { parameter }\end{array}$} & \multicolumn{2}{c}{ Neck } & \multicolumn{3}{c}{ Chest } & Width \\
\cline { 2 - 6 } & Length & $\begin{array}{c}\text { Circum- } \\
\text { ference }\end{array}$ & Length & Width & $\begin{array}{c}\text { Circum- of pubic } \\
\text { ference } \\
\text { bone }\end{array}$ \\
\hline Mean $(\mathrm{cm})$ & $22.08 \pm 1.40$ & $12.65 \pm 1.0$ & $14.82 \pm 1.278 .81 \pm 0.7738 .82 \pm 3.02$ & $2.62 \pm 0.54$ \\
Min. $(\mathrm{cm})$ & 19.00 & 10.40 & 12.60 & 7.30 & 32.00 & 1.31 \\
Max. $(\mathrm{cm})$ & 25.50 & 15.00 & 18.70 & 11.00 & 44.00 & 3.54 \\
$\begin{array}{l}\text { Coefficient } \\
\text { of variation }\end{array}$ & 1.95 & 1.00 & 1.60 & 0.59 & 9.15 & 0.30 \\
$(\%)$ & & & & & & \\
\hline
\end{tabular}

Table 3. Coefficient correlation of age, body weight, body morphometric and crowing characteristics

\begin{tabular}{lcc}
\hline & \multicolumn{2}{c}{ Crowing characteristics } \\
\cline { 2 - 3 } & Duration & Intensity (volume) \\
\hline Age & 0.75 & 0.66 \\
Bodyweight & 0.36 & 0.59 \\
Body morphometric & & \\
Length of neck & 0.46 & 0.46 \\
Circumference of neck & 0.32 & 0.38 \\
Length of chest & 0.47 & 0.68 \\
Width of chest & 0.39 & 0.66 \\
Circumference of chest & 0.34 & 0.58 \\
Width between pubic bone & 0.64 & 0.48 \\
\hline
\end{tabular}

Correlations among age, body weight and morphometric with crowing characteristics were all positive (Table 3). The strongest correlations were found between age and duration of crows (0.75) age and intensity of crows (0.66), as well as between body weight and crowing intensity (0.59). Also, relatively strong correlations are found between chest size (length (0.68), width (0.66) and circumference (0.58) of chest) with crowing intensity. Compared to other morphometric measures, width of pubic bone has the strongest correlation with crowing duration.

\section{Discussion}

Vertebrates communicate information about their social position in many ways including through acoustic signals such as crowing (Leonard and Horn 1995). In groups of roosters, crowing provides information about social hierarchy (Shimmura et al. 2015). Frequency and quality of crowing are known to vary with male status (Leonard and Horn 1995). The current study indicated that Pelung roosters in all areas have similar crowing duration, while their crowing intensity is varied. Also, the study found that age and body weight, as well as some body-morphometries, have strong correlations with crowing characteristics.

In the current study, crowing duration of Pelung averaged 8.56 seconds. This duration is shorter than that reported by Nataamijaya (2005) and Hippapi (2005). However, the crowing duration of Pelung is longer compared to other singing chickens such as Gaga dan Kokok Belengkek. Gaga produces crows of 6.71 to 7.67 seconds (Zulistiana and Abinawanto 2017), while Kokok Balenggek crow for an average of 2.08 to 4.43 seconds (Rusfidra 2007). Rusfidra et al. (2012) stated that crowing duration may be affected by time period. Roosters tend to sing longer in the mornings that in afternoons and days. In relation to Pelung contests, the contests are usually conducted in the morning until afternoon. During contests, roosters may perform differently in different time periods.

Nowadays, crowing duration of Pelung roosters seems to be lower compared to years ago. It is difficult to find a modern Pelung contest winner that can crow for 11 seconds or more. Genetic, management system and health status influence quality and duration of crowing in Pelung chickens (Jarmani and Nataamijaya 1995). Lower crowing duration might indicate a decreased genetic capacity of Pelung chickens. Muladno (2008) reported that majority of Pelung chickens traded in the markets were not purebred. Thus; controlled breeding program for the chickens is required. In terms of management system, the scarcity of feed resources due to decline of land availability as a result of increasing human population might be one reason in the long-term decline of crowing ability (Asmara 2014). Research about feed sufficiency including amounts and required nutrients to support singing ability of Pelung chickens are needed.

This study indicates that correlations between age and crowing duration of Pelung chickens are anticipated by Pelung chickens' keepers. They believe that more mature Pelung roosters would have longer crowing duration. The 
vocal organ of birds is called the syrinx (Doupe and Kuhl 1999; Suthers 2004; Suthers and Zollinger 2004).

In most birds, the syrinx is located at the junction between trachea and bronchi (Suthers 2004; Suthers and Zollinger 2004). Bird sounds are result of air flowing during expiration through syrinx (Doupe and Kuhl 1999). Wallschlager (1980) stated that bird vocalizations are determined by anatomical and physiological factors. As Pelungs grow, the important organs for birds to produce sound such as syrinx and respiratory system including lung and air sac grow to maximum capacity, which may result in longer crowing duration. The width between pubic bones may indicate of bigger essential system (and organ) to create sound in birds d, hence; the study found that there is a correlation between width of these bones with crowing duration

Crowing intensity including crowing volume is also an important factor in determining good Pelung chickens. Pelung keepers classify crowing volume as being loud, middle and low (Hippapi 2012). The current study found that the average crowing volume of Pelung is 50.11 decibels. Also, the study indicated that age and body weight may influence crowing volume of Pelung. The crowing volume found in current study was lower than that reported by the Minister of Agriculture (2011). The Ministry of Agriculture (2011) documented that crowing volume of Pelung roosters is between 60-63.89 db. In general crowing volume of Pelung roosters is assumed to be lower than that of other chicken breeds. However, more studies are needed to support this statement. Brackenbury (1978) reported that roosters are able to produce sound pressure levels in crowing of $100 \mathrm{~dB}$ measured at a distance of $1 \mathrm{~m}$. Older and heavier roosters would have louder crowing sound than those of younger and lighter birds. Brackenbury (1978) reported that bird scale may naturally influence sound production. Comparison between songbirds as group showed that the smaller birds have lower sound level pressure.

Crowing intensity is controlled by respiratory muscles and is modified by syringeal muscles which control the degree of airflow in the syrinx. This process results in some changing including the resiliency and the sound production side of syrinx as well as the production of rapid oscillatory stream fluctuations (Goller and Shutters 1996). The older and bigger birds might have stronger muscles in modulating crowing volume. The intrinsic muscles in the syrinx influence the efficiency of sound production in birds (Brackenbury 1978). It was reported that there are two muscles associated with the syrinx, namely the Musculus tracheolateralis and Musculus sternotrachealis (Kingsley et al. 2018). In particular, Suthers and Zollanger (2004) stated that song is produced during expiration and a few muscles are involved in the process. The muscles are abdominal expiratory muscles and two thoracic inspiratory muscles. A stronger rooster may have stronger abdominal expiratory muscles to modulate air sac pressure. In current study, the activity of thoracic muscles might be observed in the size of chest of the chickens.

The current study provides empirical evidence about sound characteristics of Pelung chickens that supports beliefs of the keepers. Age and body weight are important factors that should be considered by keepers before bringing their chickens into contests. However, more samples from different locations are needed to support the findings. In addition, collecting data from different contest time periods are required. This current study does not provide insight into other aspects that might influence sound performance such as management systems, health status and participation in rehearsals. Studies about these factors will be helpful for managing Pelung as AnGR in Indonesia.

\section{ACKNOWLEDGEMENTS}

This study was supported by Hibah Internal Unpad (HIU). We would like to express our gratitude to Rector of Universitas Padjadjaran, Sumedang, Indonesia for funding this study through HIU grant. We also thank to Rena Nurvadila and Lina Marlina for helping us during data collection.

\section{REFERENCES}

Asmara IY. 2014. Risk Status of Selected Indigenous Chicken Breeds in Java, Indonesia: Challenges and Opportunities for Conservation', [Dissertation]. Research Institute for the Environment and Livelihoods, Faculty of Engineering, Health, Science and the Environment, Charles Darwin University, Darwin, NT, Australia.

Asmara IY, Garnida D, Sulistyati M, Tejaningsih S, Partasasmita R. 2018. Knowledge and perception of Pelung keepers's toward chicken contests in West Java, Indonesia. Biodiversitas 19(6): 2232-2237.

Bortoluzzi C, Crooijmans RPMA, Bosse M, Hiemstra SJ. Groenen MAM, Jan Megens H. 2018. The effects of recent changes in breeding preferences on maintaining traditional Dutch chicken genomic diversity. Heredity. DOI: 10.1038/s41437-018-0072-3

Brackenbury JH. 1978. Respiratory mechanics of sound production in chickens and geese. J Exp Biol 72: 229-250.

Cianjur District Office of Information Communication and Statistics 2017. Geographical location, https://cianjurkab.go.id/profil-cianjur/letakgeografis/ [Indonesian]

Director General of Livestock Services. 2003. National report on animal genetic resources Indonesia: a strategic policy document. The Ministry of Agriculture of the Republic of Indonesia, Jakarta, Indonesia.

Diwyanto K, Prijono SN. 2007. Genetic Resources Diversity of Local Chickens in Indonesia. LIPI Press, Jakarta. [Indonesian]

Doupe AJ, Kuhl PK. 1999. Birdsong and human speech: Common themes and mechanisms. Ann Rev Neurosci 22: 567-631.

FAO. 2007. The state of food and agriculture, paying farmers for environmental services. Food and Agriculture Organization of the United Nations, Rome, Italy.

Goller F, Suthers RA. 1996. Role of Syringeal muscles in controlling the phonology of bird song. J Neurophysiol 76 (1): 287-300

Hippapi. 2005. Enchanting of animal genetic resources in Cianjur. HIPPAPI Kabupaten Cianjur, Cianjur, Indonesia. [Indonesian]

HIPPAPI. 2012. Regeneration and training for juries of Pelung chickens. HIPPAPI of Cianjur, Cianjur, West Java, Indonesia. [Indonesian]

Komiyama T, Lin M, Ogura A. 2016. A CGH analysis to estimate genetic variations among domesticated chickens. BioMed Res Intl. DOI: $10.1155 / 2016 / 1794329$.

Jarmani SN, Nataamijaya AG. 1995. Characteristics of the sound of a chicken Pelung. Proceedings of the National Seminar on Animal Husbandry and Veterinary. Center for Animal Husbandry Development. Agricultural Research and Development Agency, Bogor. [Indonesian] 
Kingsley EP, Eliason CM, Riede T, Li Z, Hiscock TW, Farnsworth M, Thomson SL, Goller F, Tabin CJ, Clarke JA. 2018. Identity and novelty in the avian syrinx. Perspective 115 (41): 10209-10217.

Leonard M L, Horn AG. 1995. Crowing in relation to status in roosters. Anim Behav 49: 1283-1290.

Ministry of Agriculture. 2011. Decree No. 2918/2011: Determination of Pelung chickens as an indigenous breed in Indonesia. Ministry of Agriculture, Jakarta. [Indonesian]

Muladno. 2008. Local chicken genetic resources and production systems in Indonesia. Food and Agriculture Organization of the United Nations, Rome, Italy.

Nataamijaya AG. 2000. The native chicken of Indonesia. Bul Plasma Nutfah 6 (1): 1-6. [Indonesian]

Nataamijaya AG. 2005. Characteristic appearance of feather, skin, foo scales, and beak color of the Pelung chicken in Garut and Sentul chicken in Ciamis. Bul Plasma Nutfah 11 (1): 1-6. [Indonesian]

Partasasmita R, Hidayat RA, Erawan TS, Iskandar J. 2016. Local knowledge of Karangwangi Village people's, Cianjur District about variation (race), the keeping activity and conservation of chicken (Gallus gallus domesticus Linnaeus, 1758). Pros Sem Nas Masy Biodiv Indon 2 (1): 113-119. [Indonesian]

Partasasmita R, Iskandar J, Rukmana. 2017. Naga people's (Tasikmalaya District West Java, Indonesia) local knowledge of the variations and traditional management farm of village chickens. Biodiversitas 18: 834-843.

Rusfidra. 2007. Bioacoustic assessment of the belengek crown chickens "the local sing fowl" from West Sumatra. National Seminar on Animal Husbandry and Veterinary Technology, Balai Besar Penelitian Veteriner, Bogor, 21-22 August. [Indonesian]

Rusfidra YY, Tumatra MH. Abbas Y, Heryandi, Arlina F. 2012 Identification of bioacoustic markings sound of crowing chicken crowing balenggek in the cage "agutalok" captive, Solok District. J Peternakan Indonesia 14 (1): 303-307. [Indonesian]

Sartika T, Iskandar S, Prasetyo LH, Takahashi H, Mitsuru M 2004. Genetic kinship of native chickens, Pelung, Sentul and black Kedu using microsatellite DNA markers: I. Group mapping on macro chromosomes. Jurnal Ilmu Ternak dan Veteriner 9 (2): 81-86. [Indonesian]

Shimmura T, Ohashi S, Yoshimura T. 2015. The highest-ranking rooster has priority to announce the break of dawn. Sci Rep 5: 11683. DOI: 10.1038/srep11683.

Sukabumi District Government, 2016. Geography of Sukabumi District. https://sukabumikab.go.id/portal/profil/geografi-kabupatensukabumi.html [Indonesian]

Sulandari S, Zein MSA, Paryanti S, Sartika T, Astuti M, Widjastuti T, Sujana E, Darana S, Setiawan I, Garnida D. 2007. Local chicken genetic resources. In: Diwyanto $\mathrm{K}$, Prijono $\mathrm{SN}$ (eds.). The Biodiversity of Indonesia's Local Chicken Resources: Benefits and Potential, LIPI Press, Jakarta. [Indonesian]

Sulandari S, Zein MSA, Sartika, T. 2008. Molecular characterization of Indonesian indigenous chicken based on mitochondrial DNA displacement (D)-loop sequences. J Biosci 5 (4): 145-154.

Suthers RA. 2004. Vocal mechanisms in birds and bats: a comparative view. Anais da Academia Brasileira de Ciências 76 (2): 247-252.

Suthers RA, Zollinger SA. 2004. Producing sound: the vocal apparatus. Ann NY Acad Sci 1016: 109-129.

Wallschlager D. 1980. Correlation of song frequency and body weight in passerine birds. Experientia 36: 412-412.

Zulistiana T, Abinawanto A. 2017. Morphometric and bioacoustic analysis gaga chicken (Gallus gallus domesticus) at Bangkalan, Kamal Madura. AIP Conf Proc 2023. 020142. DOI: $10.1063 / 1.5064139$ 